\title{
Non-Typhoidal Salmonella in poultry meat and diarrhoeic patients: prevalence, antibiogram, virulotyping, molecular detection and sequencing of class I integrons in multidrug resistant strains
}

\author{
Rasha M. Gharieb ${ }^{1 *}$, Yasmine H. Tartor ${ }^{2}$ and Mariam H. E. Khedr ${ }^{3}$
}

\begin{abstract}
Background: The worldwide increase of food-borne infections with antibiotic resistant pathogens constitutes a major public health problem. Therefore, this study aimed to determine the prevalence, antibiogram, virulence genes profiles and integron characteristics of non-typhoidal Salmonella spp. isolated from poultry meat and diarrhoeic patients in Egypt.

Methods: A total of 150 samples comprising (100 poultry meat and 50 diarrhoeic patients'stool) were examined for the presence of Salmonella spp. using culture methods followed by biochemical and serological identification of the isolates. All Salmonella strains were tested for their susceptibility to the antibiotics using disk diffusion method and screened for the presence of virulence genes and class I integrons using PCR.

Results: The overall prevalence of Salmonella spp. in poultry meat samples was $10 \%$ compared to $4 \%$ in diarrhoeic patients. All the isolates were serologically identified into Salmonella Typhimurium (seven isolates), S. Derby, S. Kiel, S. Rubislaw (one isolate, each) and untypable strains (two isolates). Antibiotic susceptibility testing showed a higher resistance of the total isolates to erythromycin and tetracycline (100\%, each), followed by amoxicillin-clavulanic acid (91.7\%), trimethoprim-sulfamethoxazole (83.3\%), streptomycin, nalidixic acid, ampicillin-sulbactam (75\%, each), gentamycin, ampicillin (66.7\%, each), chloramphenicol (58.3\%), ciprofloxacin (25\%) and ceftriaxone (16.7 \%). Virulence genes profiles revealed the presence of sopB gene in five Salmonella strains isolated from poultry meat $(n=3)$ and humans $(n=2)$. Moreover, pefA was only identified in three isolates from poultry meat. On the other hand, S. Kiel and $\mathrm{S}$. Typhimurium (one isolate, each) were harboring hilA and stn genes, respectively. Class 1 integrons were detected in all Salmonella spp. with variable amplicon sizes ranged from 650-3000 bp. Sequencing of these amplicons revealed the presence of gene cassettes harboring aac(3)-Id, aadA2, aadA4, aadA7, sat, dfrA 15, InuF and estX resistance genes. Nucleotide sequence analysis showed point mutations in the aac(3)-Id of S. Derby, aadA2, estX-sat genes of S. Typhimurium. Meanwhile, frame shift mutation was observed in aadA7 genes of $S$. Typhimurium.
\end{abstract}

Conclusions: Increasing rate of antimicrobial resistance and class 1 integrons among multidrug resistant Salmonella spp. has prompted calls for the reduction of antimicrobial use in livestock to prevent future emergence of resistance.

Keywords: Salmonella spp., Zoonoses, multidrug resistance, Virulence, Class I integrons

\footnotetext{
*Correspondence: ghariebrasha@gmail.com

1 Depatment of Zoonoses, Faculty of Veterinary Medicine, Zagazig

University, 44511 Zagazig, Egypt

Full list of author information is available at the end of the article
} 


\section{Background}

Non-typhoidal Salmonella (NTS) is one of the major zoonotic food-borne pathogens representing an important public health problem worldwide. It can cause a variety of clinical manifestations ranging from mild gastroenteritis to bacteraemia and extra intestinal localized infections involving many organs. The global burden of NTS gastroenteritis has been estimated to be 93.8 million cases of gastroenteritis each year with 155, 000 deaths annually [1]. Food of animal origin especially poultry meat is considered to be one of the major vehicles of Salmonella infections in humans and has been implicated in outbreaks of human salmonellosis [2]. Antimicrobial resistance and virulence of Salmonella strains play a vital role in systemic infections. Salmonella pathogenicity is dictated by an array of factors encoded by virulence genes that assist the organism to express its virulence in the host cells and ultimately manifest in the typical symptoms of salmonellosis. Some genes are known to be involved in adhesion and invasion including; plasmid encoded fimbriae (pefA) and hyper invasive locus (hilA) [3, 4]. Salmonella outer proteins (sop A-E) encoded by sop gene and (stn) codes for enterotoxin productions are associated with the actual manifestation of pathogenic processes [5]. In addition to virulence factors, the emergence of antimicrobial resistance among NTS has become a public health threat. Since food of animal origin is a major source of Salmonella spp., it has been suggested that abundant use of antimicrobials in food animals' production may contribute to the presence of antimicrobial resistance in these species and subsequently transferred to humans through food chain [6]. Factors contributed to the resistance and virulence of Salmonella may be located on chromosomes, plasmids, transposon and integrons. Integrons are DNA elements that can transfer antibiotic resistance genes among bacteria. Class I integrons are the most common type of integrons recognized among the multidrug resistant
(MDR) Salmonella and have conserved regions (5'-CS and $3^{\prime}-\mathrm{CS}$ ) which often contain gene cassettes [7]. These cassettes contain genes that confer resistance to antimicrobial agents including aminoglycosides, b-lactams, chloramphenicol and trimethoprim as well as genes that confer resistance to antiseptics and disinfectants [8]. The present study was undertaken to (i) trace the prevalence and antimicrobial susceptibility patterns of NTS enterica serotypes isolated from poultry meat and diarrhoeic patients (ii) ascertain the presence of virulence genes and class I integrons using PCR (iii) sequencing of the amplified DNA fragments of class I integrons in order to identify the resistance genes located in integron gene cassettes.

\section{Results and discussion}

Prevalence of Salmonella serovars in poultry meat and diarrhoeic patients

In the present study, the overall prevalence of Salmonella spp. in the total examined poultry meat samples was $10 \%$ (Table 1). This result was compatible with previous studies in Nepal [9]. Moreover, our results regarding the prevalence of Salmonella spp. in broiler chicken meat (14\%) substantiate the findings of others in Canada [10].

Serotyping of Salmonella spp. isolated from poultry meat in this study revealed the predominance of $S$. Typhimurium in chicken meat and this was in concordance with previous studies from India [11]. Additionally, other serovars such as $S$. Rubislaw, $S$. Kiel (chicken meat) and $S$. Derby (duck meat) were identified.

It was obvious from Table 1 that $4 \%$ ( 2 out of 50 ) of stool samples from diarrhoeic patients were positive for Salmonella spp. and S. Typhimurium was the only serotype identified. Nearly similar prevalence in diarrhoeic patients was reported in India [12]. The isolation of $S$. Derby from poultry meat and humans has been previously recorded in Netherlands [13]. Moreover, $S$. Rubislaw was isolated from chicken meat in Senegal and

Table 1 Frequency distribution of Salmonella serovars in poultry meat and diarrhoeic patients

\begin{tabular}{|c|c|c|c|c|c|}
\hline \multirow[t]{3}{*}{ Source } & \multicolumn{3}{|l|}{ Poultry meat } & \multirow[t]{2}{*}{ Diarrhoeic patients $(n=50)$} & \multirow[t]{2}{*}{ Total (150) } \\
\hline & Chicken $(n=50)$ & Duck $(n=50)$ & Total $(n=100)$ & & \\
\hline & No. $(\%)$ & No. $(\%)$ & No. (\%) & No. (\%) & No. (\%) \\
\hline \multicolumn{6}{|l|}{ Serotype } \\
\hline S. Typhimurium $\left(\mathrm{O} 1,4,[5], 12 \mathrm{H}_{1}\right.$ : i $\left.\mathrm{H}_{2}: 1,2\right)$ & $5(10)$ & $0(0)$ & $5(5)$ & $2(4)$ & $7(4.7)$ \\
\hline S. Rubislaw $\left(\mathrm{O} 11 \mathrm{H}_{1}\right.$ : r H2: e,n,x) & $1(2)$ & $0(0)$ & $1(1)$ & $0(0)$ & $1(0.7)$ \\
\hline S. Kiel $\left(\mathrm{O} 1,2,12 \mathrm{H}_{1}: \mathrm{g}, \mathrm{p} \mathrm{H}_{2}:-\right)$ & $1(2)$ & $0(0)$ & $1(1)$ & $0(0)$ & $1(0.7)$ \\
\hline S. Derby $\left(01,4,[5], 12 \mathrm{H}_{1}: \mathrm{f}, \mathrm{g} \mathrm{H} 2:[1,2]\right)$ & $0(0)$ & $1(2)$ & $1(1)$ & $0(0)$ & $1(0.7)$ \\
\hline Untypable & $0(0)$ & $2(4)$ & $2(2)$ & $0(0)$ & $2(1.3)$ \\
\hline Total & $7(14)$ & $3(6)$ & $10(10)$ & $2(4)$ & $12(8)$ \\
\hline
\end{tabular}


diarrhoeic children in Gambia [14] and this confirms the zoonotic importance of the former serotypes.

\section{Antibiotic susceptibility testing}

All Salmonella isolates were tested for their susceptibility towards antimicrobial drugs (Table 2). The results highlighted the higher resistance of the isolates to erythromycin and tetracycline (100\%, each), followed by amoxicillin-clavulanic acid (91.7\%), trimethoprimsulfamethoxazole $(83.3 \%)$, streptomycin, nalidixic acid, ampicillin-sulbactam (75\%, each), gentamycin, ampicillin $(66.7 \%$, each), chloramphenicol (58.3\%), ciprofloxacin $(25 \%)$ and ceftriaxone (16.7 \%). This isn't surprising because these antibiotics are cheap, easily affordable and commonly used in humans and poultry without prescription. In poultry, these drugs are used either for therapeutic purposes or as growth promoters added to the feed leading to the development of resistance in the enteric bacterial flora of poultry. Subsequently the pathogenic bacteria such as Salmonella may acquire resistance from this enteric flora and transfer this resistance to human's strains through food chain leading to the emergence of MDR Salmonella strains that constitute a public health risk and potentially affect the efficacy of drug treatment in humans. It was obvious from Table 2 that $100 \%$ of Salmonella spp. isolated from poultry meat were resistant to each of erythromycin and tetracycline, 9 (90\%) were resistant to amoxicillin-clavulanic acid, 8 (80 \%) showing resistance to trimethoprim-sulfamethoxazole, 7 (70 \%) exhibiting resistance to each of streptomycin, ampicillinsulbactam, nalidixic acid and gentamycin. Moreover, the lower resistance rates to chloramphenicol (50\%), ciprofloxacin $(30 \%)$ and ceftriaxone $(10 \%)$ were observed.
Nearly similar resistance rate to ampicillin, streptomycin, nalidixic acid, tetracycline and trimethoprim-sulfamethoxazole was recorded in Salmonella spp. isolated from chicken meat in Pakistan [15]. On the contrary, the lower resistance rate to ceftriaxone and ciprofloxacin corroborates with others in India [11].

Table 2 also showed that all Salmonella isolates of human origin were resistant to ampicillin, erythromycin, streptomycin, tetracycline, ampicillin-sulbactam, trimethoprim- sulfamethoxazole, chloramphenicol, nalidixic acid and amoxicillin-clavulanic acid. Conversely, the resistance to ceftriaxone and gentamycin was found in $50 \%$ of the isolates. On the other hand, none of the isolates was resistant to ciprofloxacin. Consistent with our results, a higher resistance rate $(100 \%)$ to ampicillin, chloramphenicol, streptomycin, trimethoprimsulfamethoxazole and tetracyclines was recorded in $S$. Typhimurium strains isolated from diarrhoeic patients in Kenya [16]. Another worrisome situation in this study is that, $50 \%$ of Salmonella isolates from diarrhoeic patients were resistant to ceftriaxone and gentamycin. This is of particular concern because the extended spectrum cephalosporins such as ceftriaxone are the antibiotics of choice for treatment of invasive salmonellosis in children and the emergence of resistance toward these drugs could be attributed to inappropriate use of them in treatment of Salmonella infections in humans. The higher susceptibility of $S$. Typhimurium isolated from human source to ciprofloxacin (100 \%) in this study may be due to discriminate use of this drug because it is relatively expensive, not easily affordable to all people, not sold in private pharmacies without prescription. This result corroborates the findings of other investigators in Kenya

Table 2 Antibiogram of Salmonella serovars isolated from poultry meat and diarrhoeic patients

\begin{tabular}{|c|c|c|c|c|c|c|c|c|c|c|c|c|}
\hline \multirow[t]{2}{*}{ Sources/serovars } & \multicolumn{12}{|c|}{ Antibiotic (concentration $\mu \mathrm{g}$ ) } \\
\hline & $A(10)$ & $E(15)$ & $S(10)$ & $C x(5)$ & $\mathrm{T}(30)$ & Co (30) & As (20) & Sxt (25) & $C(30)$ & $\mathrm{Na}(30)$ & G (10) & Amc (30) \\
\hline Chicken meat (7) & $4(57.1)$ & $7(100)$ & $5(71.4)$ & $2(28.6)$ & $7(100)$ & $1(14.3)$ & $5(71.4)$ & $6(85.7)$ & $4(57.1)$ & $5(71.4)$ & $6(85.7)$ & $6(85.7)$ \\
\hline S. Typhimurium (5) & $2(20)$ & $5(100)$ & $4(80)$ & $2(40)$ & $5(100)$ & $1(20)$ & $4(80)$ & $5(100)$ & $3(60)$ & $4(80)$ & $5(100)$ & $4(80)$ \\
\hline S. Kiel (1) & $1(100)$ & $1(100)$ & 0 & 0 & $1(100)$ & 0 & 0 & 0 & 0 & 0 & 0 & $1(100)$ \\
\hline S. Rubislaw (1) & $1(100)$ & $1(100)$ & $1(100)$ & 0 & $1(100)$ & 0 & $1(100)$ & $1(100)$ & $1(100)$ & $1(100)$ & $1(100)$ & $1(100)$ \\
\hline Duck meat (3) & $2(66.7)$ & $3(100)$ & $2(66.7)$ & $1(33.3)$ & $3(100)$ & 0 & $2(66.7)$ & $2(66.7)$ & $1(33.3)$ & $2(66.7)$ & $1(33.3)$ & $3(100)$ \\
\hline S. Derby(1) & 0 & $1(100)$ & $1(100)$ & 0 & $1(100)$ & 0 & 0 & 0 & 0 & 0 & 0 & $1(100)$ \\
\hline Untypable(2) & $2(100)$ & $2(100)$ & $1(50)$ & $1(50)$ & $2(100)$ & 0 & $2(100)$ & $2(100)$ & $1(50)$ & $2(100)$ & $1(50)$ & $2(100)$ \\
\hline Total (10) & $6(60)$ & $10(100)$ & $7(70)$ & $3(30)$ & $10(100)$ & $1(10)$ & $7(70)$ & $8(80)$ & $5(50)$ & $7(70)$ & $7(70)$ & $9(90)$ \\
\hline Human (2) S. Typhimurium & $2(100)$ & $2(100)$ & $2(100)$ & 0 & $2(100)$ & $1(50)$ & $2(100)$ & $2(100)$ & $2(100)$ & $2(100)$ & $1(50)$ & $2(100)$ \\
\hline Total sensitive (\%) & $2(16.7)$ & 0 & $2(16.7)$ & $4(33.3)$ & 0 & $4(33.3)$ & $1(8.3)$ & $2(16.7)$ & $2(16.7)$ & 0 & $2(16.7)$ & 0 \\
\hline Total intermediate (\%) & $2(16.7)$ & 0 & $1(8.3)$ & $5(41.7)$ & 0 & $6(50)$ & $2(16.7)$ & 0 & $3(25)$ & $3(25)$ & $2(16.7)$ & $1(8.3)$ \\
\hline Total resistant (\%) & $8(66.7)$ & $12(100)$ & $9(75)$ & $3(25)$ & $12(100)$ & $2(16.7)$ & $9(75)$ & $10(83.3)$ & $7(58.3)$ & $9(75)$ & $8(66.7)$ & $11(91.7)$ \\
\hline
\end{tabular}

A Ampicillin, E Erythromycin, S Streptomycin, Cx Ciprofloxacin, TTetracycline, Co Ceftriaxone, As Ampicillin-Sulbactam, Sxt Trimethoprim-Sulfamethoxazole, $C$ Chloramphenicol, Na Nalidixic acid, G Gentmycin, Amc Amoxicillin-Clavulanic acid 
[16]. Therefore, ciprofloxacin still to have a high potency against NTS strains in humans and continue to be the most successful drug used for treatment of septicaemic salmonellosis in adult humans. The increased resistance of $S$. Typhimurium isolated from humans to quinolones (nalidixic acid) in this study (100\%) is a matter of concern and could be attributed to indiscriminate use of these antibiotics by human patients. Moreover, the presence of these drug residues in food of animal origin may results in increased resistance among human's isolates.

Table 3 verified that all Salmonella spp. isolated from poultry and humans were MDR, exhibiting resistance to at least four or more antibiotics displayed by ten resistance patterns.

\section{Molecular detection of Salmonella virulence genes (virulotyping)}

Table 3 revealed the presence of pefA gene among three Salmonella strains isolated from poultry meat, belonged to $S$. Rubislaw, $S$. Typhimurium and untypable strain (one isolate, each) (Fig. 1). Moreover, hilA gene was only identified in one isolate of $S$. Kiel (Fig. 2). Furthermore, three Salmonella isolates from poultry meat comprising untypable strains (two isolates) and $S$. Typhimurium (one isolate) were harboring $\operatorname{sop} \mathrm{B}$ gene (Fig. 3). The detection of pefA gene in S. Rubislaw in Gambia and Senegal [14] and $S$. Typhimurium in India [4] was previously reported. On the other hand, hilA gene was identified in Salmonella serotypes isolated from chickens in Iran [17].

It was obvious from Table 3 that all $S$. Typhimurium isolates from humans were harboring $\operatorname{sop} \mathrm{B}$ compared to one isolate had stn gene (Figs. 3, 4). Consistent with our findings, $s o p$ B gene was previously identified in $S$. Typhimurium isolated from diarrhoeic patients and birds in India [18]. Meanwhile, stn gene was detected in S. Typhimurium isolated from humans in India [4].

\section{Molecular detection and sequencing of class 1 integrons}

A notable feature in this study is that all Salmonella strains isolated from poultry meat and humans were MDR and harboring class I integrons that are chromosomally located (Fig. 5). Ten different profiles of class I integrons with variable amplicon sizes ranged from 6503000 bp were observed (Table 3). Similarily, class I integrons were detected in $97 \%$ of $S$. Typhimurium isolated from Norwegian diarrhoeic patients [19]. On the contrary, a lower detection rate (9\%) was recorded in Salmonella spp. isolated from poultry meat [20]. Sequencing

Table 3 Resistance pattern, virulence genes and class I integron profiles among multidrug resistant Salmonella serotypes in this study

\begin{tabular}{|c|c|c|c|c|c|c|c|c|c|c|}
\hline \multirow{2}{*}{$\begin{array}{l}\text { Strain } \\
\text { no. }\end{array}$} & \multirow{2}{*}{$\begin{array}{l}\text { Serovar (source } \\
\text { of isolate) }\end{array}$} & \multirow{2}{*}{$\begin{array}{l}\text { Resistance pat- } \\
\text { tern }\end{array}$} & \multicolumn{4}{|c|}{ Virulence genes } & \multirow{2}{*}{$\begin{array}{l}\text { Integron } \\
\text { amplicon } \\
\text { size (bp) }\end{array}$} & \multirow{2}{*}{$\begin{array}{l}\text { Integron } \\
\text { profile (IP) }\end{array}$} & \multirow{2}{*}{$\begin{array}{l}\text { Genes in the } \\
\text { cassettes }\end{array}$} & \multirow{2}{*}{$\begin{array}{l}\text { Accession } \\
\text { numbers }\end{array}$} \\
\hline & & & PefA & hilA & Sop B & Stn & & & & \\
\hline 1 & S. Derby (duck) & STE Amc & - & - & - & - & $\begin{array}{l}937 \\
1600\end{array}$ & । & $\begin{array}{l}\operatorname{aac}(3)-I d a a c \\
\text { (3)-Id, aadA7 }\end{array}$ & $\begin{array}{l}\text { KT581257 } \\
\text { KT427378 }\end{array}$ \\
\hline 2 & S. Kiel (chicken) & ATEAmc & - & + & - & - & 937 & ॥ & & \\
\hline 3 & Untypable (duck) & $\begin{array}{l}\text { A C S SxtTE CX As } \\
\text { Na G Amc }\end{array}$ & + & - & + & - & 1500 & III & $\operatorname{aac}(3)-I d$, aadA7 & KT581256 \\
\hline 4 & $\begin{array}{l}\text { S. Rubislaw } \\
\text { (chicken) }\end{array}$ & $\begin{array}{l}\text { A C S Sxt TE As Na } \\
\text { G Amc }\end{array}$ & + & - & - & - & 1500 & III & - & \\
\hline 5 & $\begin{array}{l}\text { S. Typhimurium } \\
\text { (chicken) }\end{array}$ & $\begin{array}{l}\text { A C S Sxt TE As Na } \\
\text { G Amc }\end{array}$ & - & - & - & - & $\begin{array}{l}1100 \\
1500\end{array}$ & IV & $\begin{array}{l}- \\
\text { estX-sat }\end{array}$ & KT581255 \\
\hline 6 & $\begin{array}{l}\text { S. Typhimurium } \\
\text { (chicken) }\end{array}$ & $\begin{array}{l}\text { S SxtTECxCo } \\
\quad \mathrm{NaG}\end{array}$ & - & - & + & - & $\begin{array}{l}650 \\
1550\end{array}$ & V & $\begin{array}{l}\text { sat } \\
\text { ac (3)-Id, aadA7at }\end{array}$ & $\begin{array}{l}\text { KT449570 } \\
\text { KT598359 }\end{array}$ \\
\hline 7 & Untypable (duck) & $\begin{array}{l}\text { A Sxt T E As Na } \\
\text { Amc }\end{array}$ & - & - & + & - & $\begin{array}{l}1600 \\
3000\end{array}$ & $\mathrm{VI}$ & - & \\
\hline 8 & $\begin{array}{l}\text { S. Typhimurium } \\
\text { (human) }\end{array}$ & $\begin{array}{l}\text { A C S Sxt T E Cro } \\
\text { As Na G Amc }\end{array}$ & - & - & + & - & 1000 & VII & - & \\
\hline 9 & $\begin{array}{l}\text { S. Typhimurium } \\
\text { (human) }\end{array}$ & $\begin{array}{l}\text { A C S Sxt TE As Na } \\
\text { Amc }\end{array}$ & - & - & + & + & $\begin{array}{l}650 \\
750 \\
1600\end{array}$ & VIII & $\begin{array}{l}\operatorname{adA4} \\
\text { adfrA15 }\end{array}$ & $\begin{array}{l}\text { KT581253 } \\
\text { KT449571 }\end{array}$ \\
\hline 10 & $\begin{array}{l}\text { S. Typhimurium } \\
\text { (chicken) }\end{array}$ & S Sxt TE As G Amc & - & - & - & - & 1900 & IX & & \\
\hline 11 & $\begin{array}{l}\text { S. Typhimurium } \\
\text { (chicken) }\end{array}$ & $\begin{array}{l}\text { A C S Sxt TE As Na } \\
\text { G Amc }\end{array}$ & - & - & - & - & 1900 & IX & $\operatorname{aadA2}$, InUF & KT449569 \\
\hline 12 & $\begin{array}{l}\text { S. Typhimurium } \\
\text { (chicken) }\end{array}$ & $\begin{array}{l}\text { C SxtT E Cx As Na } \\
\text { G Amc }\end{array}$ & + & - & - & - & 1550 & $x$ & $\operatorname{aac}(3)-I d$, a adA7 & KT581254 \\
\hline
\end{tabular}




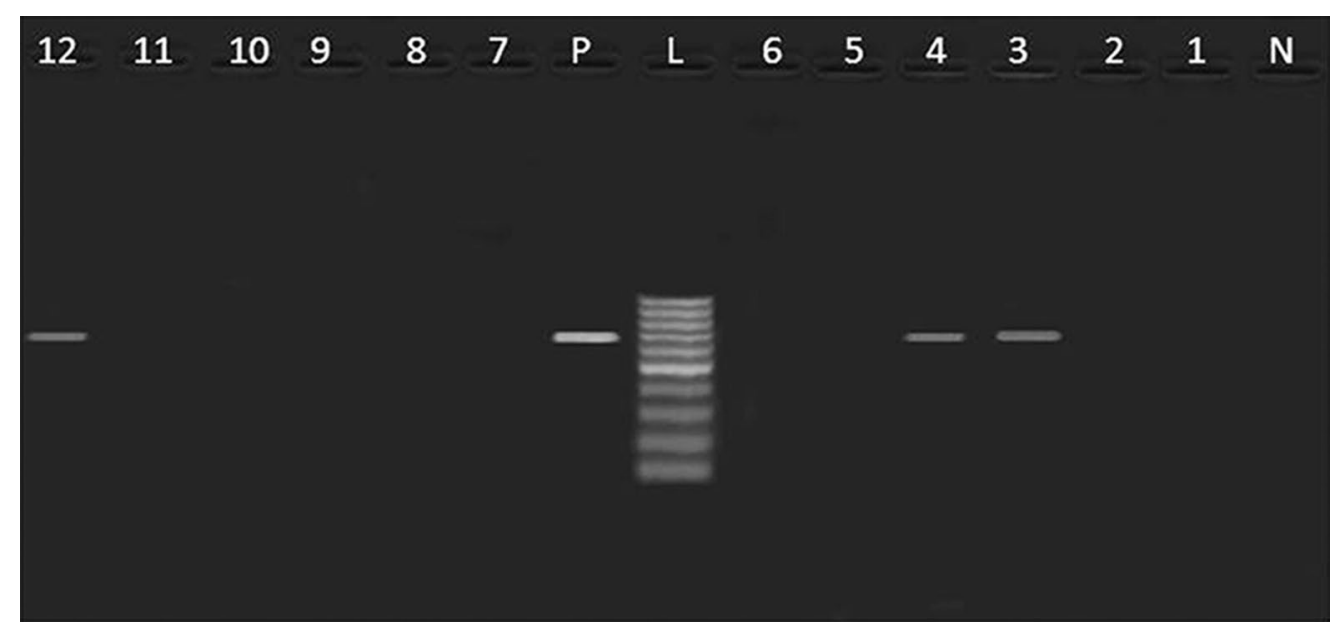

Fig. 1 Agarose gel electrophoresis showing an amplification of pefA gene (700 bp) in Salmonella isolates from poultry meat and humans. Lane N: negative control (pefA- Salmonella strain), lane L: DNA ladder (100 bp), lane P: positive control (pefA ${ }^{+}$Salmonella strain), lane 1: pefA- (S. Derby, duck), lane 2: $\operatorname{pefA}^{-}$(S. Kiel, chicken), lane3: pefA+ (untypable, duck), lane 4: pefA+ (S. Rubislaw, chicken), lanes 5,6, 10, 11: pefA- (S. Typhimurium, chicken), lane 7: pefA- $^{-}$(untypable, duck), lanes 8,9: $\operatorname{pefA}^{-}$(S. Typhimurium, humans), lane12: pefA ${ }^{+}$(S. Typhimurium, chicken)

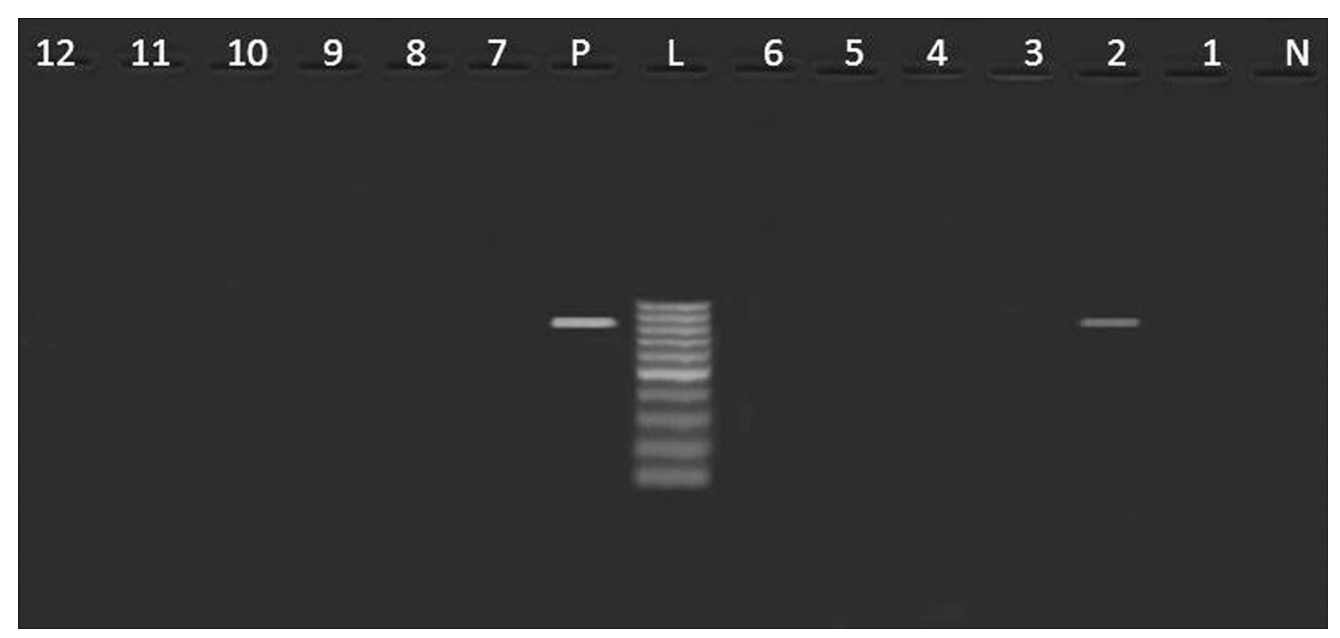

Fig. 2 Agarose gel electrophoresis showing an amplification of hilA gene (854 bp) in Salmonella isolates from poultry meat and humans. Lane $\mathrm{N}$ : negative control (hilA- Salmonella strain), lane L: DNA ladder (100 bp), lane P: Positive control (hilA+ Salmonella strain), lane 1: hil/ ${ }^{-}$(S. Derby, duck), lane 2: hilA+ (S. Kiel, chicken), lane 3,7: hilA- (untypable, duck), lane 4: hilA- (S. Rubislaw, chicken), lanes 5, 6, 10, 11,12: hilA- (S. Typhimurium, chicken), lanes 8,9: hilA- (S. Typhimurium, humans)

of the variable amplicons of class I integrons denoted by asterisks (Fig. 5) revealed the presence of gene cassettes containing aminoglycoside acetyltransferase [aac(3)-Id or aacCA5] gene which confers resistance against gentamycin, aminoglycoside adenyltransferase (aadA2, aadA4, aadA7) genes that confer resistance to streptomycin and spectinomycin, streptothricin acetyltransferase (sat) encoding resistance against streptothricin, dihydrofolate reductase type 15 (dfrA15) that confers resistance to trimethoprim, lnuF gene that codes for lincosamides resistance (lincomycin and clindamycin) and putative esterase (estX). Interestingly, the aac (3)-Id plus aadA7 were the most predominant resistance genes identified in class I integron gene cassettes of 1600 bp ( $S$. Derby, duck), 1500 bp (untypable strain, duck) and 1550 bp (S. Typhimurium, chicken). The same cassettes harboring aac (3)-Id and aadA7 genes were previously identified in class I integron of $S$. Haifa (GenBank accession no. AY563051) [21], S. Newport (AY458224) [22] and $S$. Kentucky (AY463797) [23]. Despite the presence of these genes, some strains such as $S$. Derby was susceptible to gentamycin and $S$. Typhimurium strains (chicken) were 


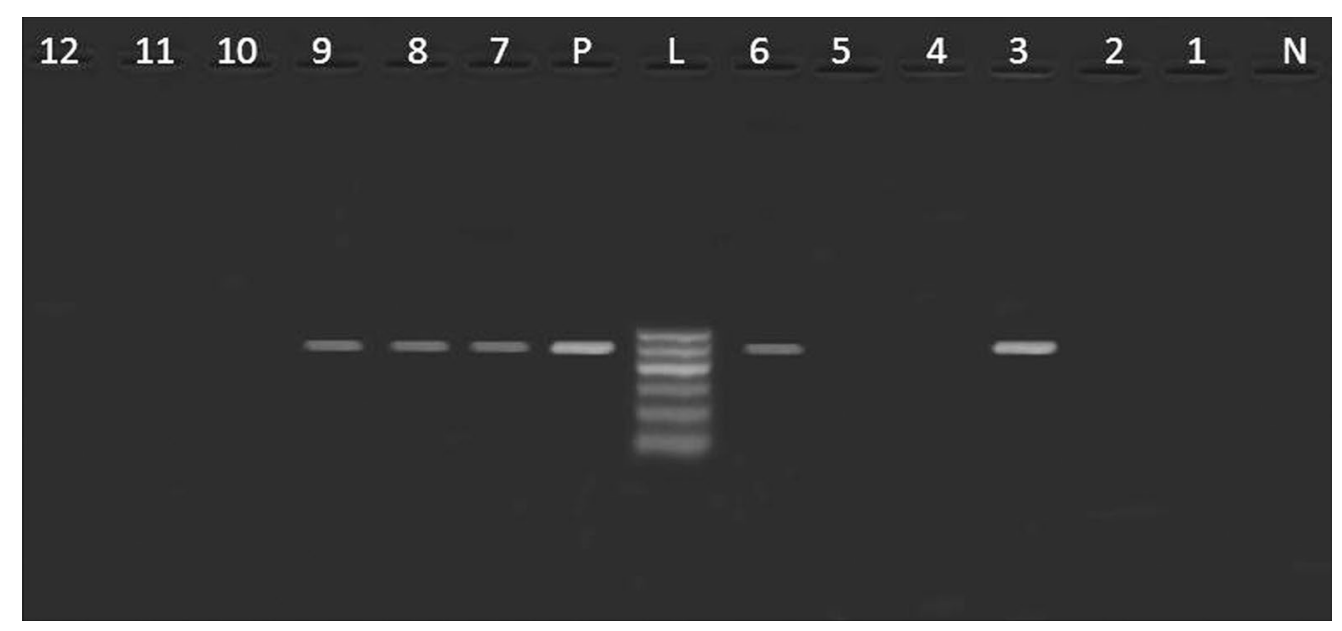

Fig. 3 Agarose gel electrophoresis showing an amplification of sopB gene (517 bp) in Salmonella isolates from poultry meat and humans. Lane N: negative control (sopB- Salmonella strain), lane L: DNA ladder (100 bp), lane P: Positive control (sopB ${ }^{+}$Salmonella strain), lane 1: sopB ${ }^{-}$(S.Derby, duck), lane 2: $\operatorname{sopB}^{-}$(S. Kiel, chicken), lanes 3, 7: sopB $B^{+}$(untypable, duck), lane 4: sopB- (S. Rubislaw, chicken), lanes 5: sopB ${ }^{-}$(S. Typhimurium, chicken), lane 6: $\operatorname{sop}^{+}$(S. Typhimurium, chicken), lanes 8,9: $\operatorname{sopB}^{+}$(S. Typhimurium, humans), lane 10, 11, 12: sopB ${ }^{-}$(S. Typhimurium,chicken)

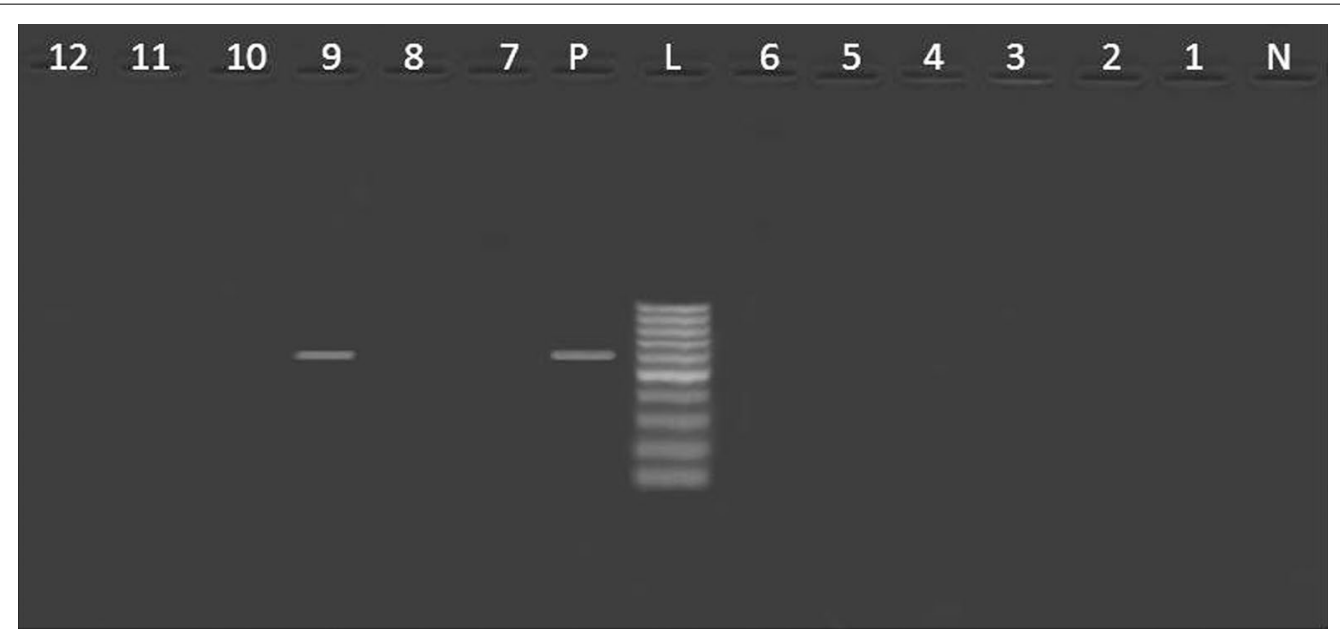

Fig. 4 Agarose gel electrophoresis showing an amplification of stn gene (617 bp) in Salmonella isolates from poultry meat and humans. Lane N: negative control (stn- Salmonella strain), lane L: DNA ladder (100 bp), lane P: Positive control (stn+ Salmonella strain), lane 1: $\operatorname{stn}^{-}$(S. Derby, duck), lane 2: $\operatorname{stn}^{-}$(S. Kiel, chicken), lanes 3,7: $\operatorname{stn}^{-}$(untypable, duck), lane 4: $\operatorname{stn}^{-}$(S. Rubislaw, chicken), lanes 5,6,10,11,12: $\operatorname{stn}^{-}$(S. Typhimurium, chicken), lane 8: $\operatorname{stn}^{-}$(S. Typhimurium, humans), lane 9: $\operatorname{stn}^{+}$(S. Typhimurium, humans)

sensitive to streptomycin and this could be attributed to point mutations in the aac(3)-Id gene of $S$. Derby [24] and frame shift mutation in $S$. Typhimurium [25, 26]. Nucleotide sequence analysis revealed point mutations in the aac(3)-Id gene of $S$. Derby leading to the amino acid changes at codon 36 (glutamine $\mathrm{CAG} \rightarrow$ proline

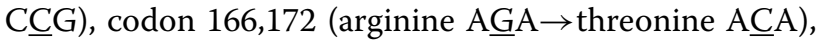

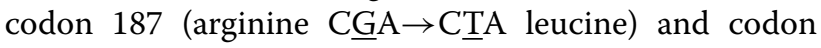
189 (cysteine TGC $\rightarrow$ arginine CGC).C-to-T transition at position 208 of the deduced polypeptide resulted in a leucine to phenylalanine substitution and $\mathrm{A}$ to $\mathrm{C}$ transversion at codon 214 resulted in asparagine to histidine substitution. Silent mutation was recorded only at nucleotide 138 and didn't result in amino acid substitution (CCA $\rightarrow$ CCG , both are proline). Moreover, sequence analysis of aadA7 gene showed frame shift mutation due to additional cytosine at position 969 of the deposited sequence of $S$. Typhimurium from chicken.

In the present study, only one isolate of $S$. Typhimurium from human was found to harbor class I integrons of 650, 750 and $1600 \mathrm{bp}$. Sequence analysis of $650 \mathrm{bp}$ revealed the presence of gene cassette containing aadA4 


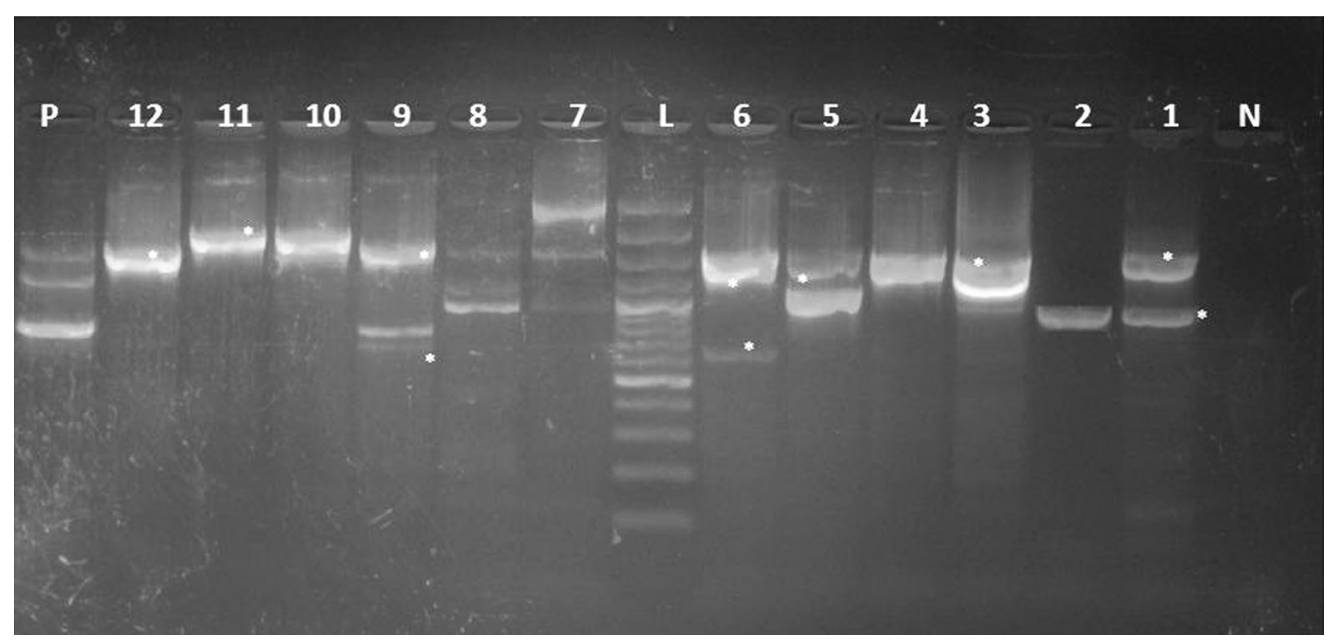

Fig. 5 Amplification of conserved regions (5'-CS and 3'-CS) of class 1 integron and integron profiles (IPs) detected in Salmonella isolates from poultry meat and humans. Asterisks represent the bands selected for sequencing. Lane N: negative control, lane L: DNA ladder (100 bp), lane P: Positive control, lane 1: IP I (S. Derby, duck), lane 2: IP II (S. Kiel, chicken), lanes 3,4: IP III (untypable, duck \& S. Rubislaw, chicken), lanes 5, 6, 10,11, 12: IP IV, V, IX X (S. Typhimurium, chicken), lanes 8, 9: IPs VIII, VIII (S. Typhimurium, humans)

which showed $100 \%$ identity with aadA4 previously identified in class I integron of $S$. Newport (CP006631) and plasmid of $S$. Indiana (ref|NG_041636). In addition, the 1600 bp integron carried gene cassette containing dfrA15 gene that showed $100 \%$ amino acid and nucleotide homology with $d f r A 15$ gene previously reported in $S$. enterica strain (KM823524).

The sat gene detected in the gene cassette of class I integron (650 bp) of $S$. Typhimurium in this study was previously identified in S. Kedougou (DQ284538) [27] and plasmid of S. Choleraesuis (AY509004) [28]. Moreover, the 1500 bp amplicon identified in S. Typhimurium contained est $X$-sat gene cassette that is identical to est $\mathrm{X}$ gene previously identified in $S$. Typhimurium (EF051039), sat gene of $S$. Choleraesuis plasmid (ref|NG_036624) and SC-B67 strain (AY509004). Point mutations were observed in est $X$-sat gene cassette in this study compared to the classical est $X$ and sat genes ( $99 \%$ nucleotide identity); these genes displayed both missense and silent mutations. The nucleotide number 763 of est $X$ was exchanged from $\mathrm{T}$ to $\mathrm{C}$ resulting in exchange of amino acid (phenylalanine) into leucine. Furthermore, at codon 288 (histidine $\mathrm{TAC} \rightarrow$ tyrosine $\underline{\mathrm{CAC}}$ ) and 290 (threonine $\underline{\mathrm{ACA}} \rightarrow$ alanine $\underline{\mathrm{GCA}}$ ). Silent mutations were recorded at nucleotides 894 (GTC $\rightarrow$ GTA, alanine), 903 (TAT $\rightarrow$ TAC, tyrosine) and 927 (GTC $\rightarrow$ GTA, both are valine). While in sat gene, silent mutations were detected at codon 418 (ACT $\rightarrow$ ACC, tyrosine), 428 (GTC $\rightarrow$ GTA, valine), 451 and 453 (GGC $\rightarrow$ GGT, GGA $\rightarrow$ GGG both are glycine). Amino acids replacement was recorded in sat gene at codon 459 (lysine $\underline{\mathrm{AAA}} \rightarrow$ glutamic acid $\underline{\text { GAA), }} 462$ (proline $\mathrm{C} \underline{\mathrm{CG}} \rightarrow$ leucine C$\underline{\mathrm{T} G}$ ) and 465 (isoleucine $\mathrm{ATC} \rightarrow$ threonine $\mathrm{ACC}$ ). Nonsense mutation was predicted at nucleotide 1418 (serine $\mathrm{T} \underline{\mathrm{C}} \rightarrow$ stop codon TAA). Antimicrobial drug resistance can occur by point mutations in the bacterial genome [29] or through mobile genetic elements called integrons which are able to disseminate the antimicrobial resistance among the enterobacteriaceae by horizontal transfer [30].

In fact, this study reports for the first time the presence of $a$ adA2 plus $\ln u F$ genes within the same integron gene cassette of 1900 bp in S.typhimurium from chicken. The nucleotide sequence of $a a d A 2$ and $\ln u F$ genes, respectively showed 99 and $100 \%$ identity with aadA2 and lnuF genes previously reported in S. enterica serovar Stanley (EU118119). Moreover, the aadA2 gene had $99 \%$ amino acid and nucleotide homology with aadA2 previously identified in $S$. Typhimurium isolated from food-animals and humans in Mexico (FJ460233) [31]. On the other hand, the 1900 bp of class I integron was found to harbor aadA2 plus dfrA12 in S. enterica serovar Typhimurium isolated from food-animals, chicken and humans in Malaysia [32].

The nucleotide sequence of aadA2 showed four base differences from other aadA2 in GenBank reported cassettes and this caused point mutation which are responsible for an alteration in the codon 60 (glycine GGA $\rightarrow$ arginine CGA), codon 61(isoleucine $\mathrm{ATC} \rightarrow$ threonine $\mathrm{A} \underline{C} \mathrm{C}$ ), codon 62 (asparagine $\underline{\mathrm{A} A C} \rightarrow$ aspartic acid $\underline{\mathrm{GAC}}$ ) and codon 105 (proline $\mathrm{CCT} \rightarrow$ TCT serine) (Fig. 6). Similarly, point mutation in the aadA2 gene of NTS enterica isolates was reported [29]. 
NG_035148.1 S.Enteritidis PSAL

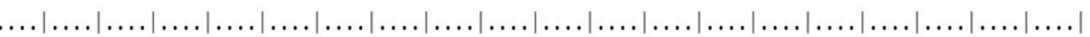
KT449569 S.TYphimurium MASR15 FDVMEQQRCYAAGQSPXNKVRHHEGSGDHRNFEPTIRGARRHX XPSGINVAGRAFVRLRSGWRPEAIQRYXVVGYCGRKAXXDAASIAQXPYGGFGEPW AF071555.1 S.Typhimurium DT10

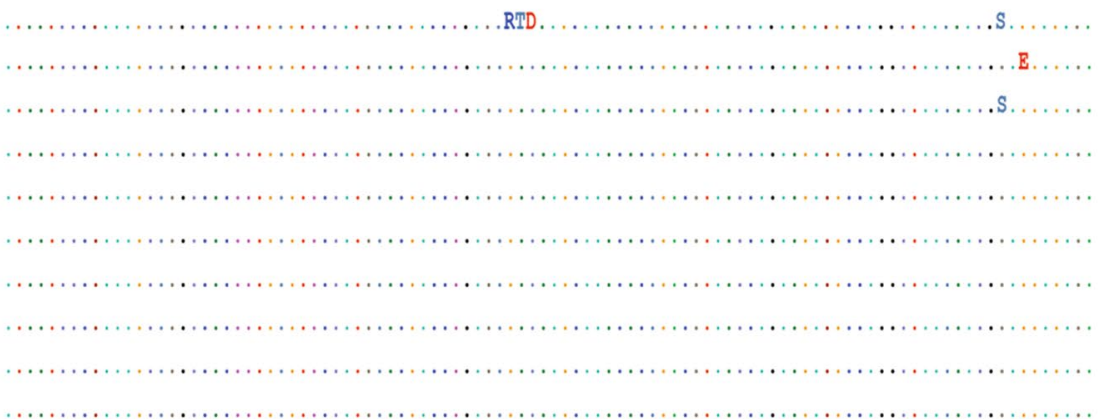
AY263740.1 Salmonella spp. S14 DQ133165. S. Typhimurium RJ460233.1 S. Typhimurium AB126602.1 S. Typhimurium AF261825.2 S.Typhimurium BU118119.1 S.Stanley DQ836009.1 S.Stanley FJ594765.1 S.Derby

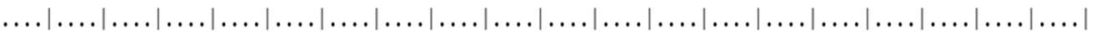
NG_035148.1 s.Enteritidis pSAL RERDAPRYRSHPCRAXRHHPVALSGXARAAIWRMAQXHSCGYLRASHDRHXSSYPAYKSKRIXRCLGRSGSGGILXPGSXIGSIRGAEGNLEAMRLAAR KT449569 S.TYphimurium MASR15 AF071555.1 S.Typhimurium DT10 AY263740.1 Salmonella spp. DQ133165. S. Typhimurium FJ460233.1 S.Typhimurium AB126602.1 S.Typhimurium AF261825.2 S.Typhimurium BU118119.1 S.Stanley DQ836009.1 S.Stanley FJ594765.1 S.Derby

NG_035148.1 S.Enteritidis pSAL KT449569 s.TYphimurium MASR15 AF071555.1 S.Typhimurium DT10 AY263740.1 Salmonella spp. DQ133165. S. TYphimurium FJ460233.1 s.Typhimurium AB126602.1 S.Typhimurium AF261825.2 S.TYphimurium BU118119.1 S.Stanley DQ836009.1 S.Stanley FJ594765.1 $S$. Derby

$\ldots . \ldots|\ldots| \ldots|\ldots| \ldots|\ldots| \ldots|\ldots| \ldots|\ldots| \ldots|\ldots| \ldots|\ldots| \ldots|\ldots| \ldots|\ldots| \ldots|\ldots| \ldots|\ldots| \ldots|\ldots|$ LGRRXAKCSAYVVPHLVQRNNRQNRAEGCRCRLGNKT PTCPVSARLTX XX SLSGTKRRSL GLTRRSL GRIYSLCERRDHQVSWXMMSNNSFKPTALRAA

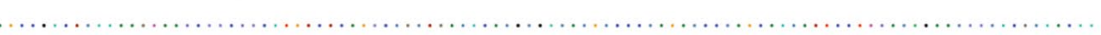


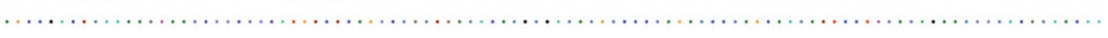

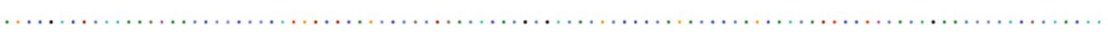

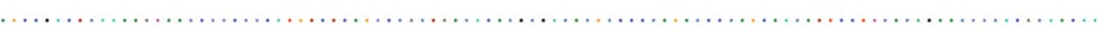

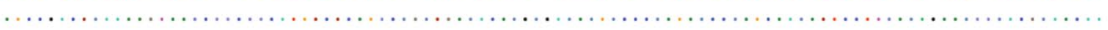
(n. 

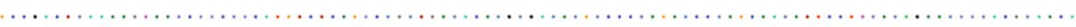

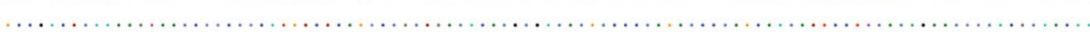

NG_035148.1 S.Enteritidis PSAL AXLRR KT449569 S.TYphimurium MASR15 AF071555.1 S.TYphimurium DT10 AY263740.1 Salmonella spp.S14 DQ133165. S.TYphimurium FJ460233.1 S.TYphimurium AB126602.1 S.TYphimurium AF261825.2 S.Typhimurium EU118119.1 S.Stanley DQ836009.1 S.Stanley FJ594765.1 S.Derby

Fig. 6 Amino acid sequence similarities for S. Typhimurium aadA2 gene of the strain under study (S. Typhimurium strain MASR STKT449569) and the reference strains. Dots indicate amino acid positions that are identical to the corresponding S. Typhimurium aadA2 sequence. The glycine 60 , isoleucine 61, asparagine 62 and proline 105 in which mutations occur are indicated by the solid bars 


\section{Conclusions}

The higher resistance rates displayed by Salmonella isolates in this study to the antibiotics and the detection of class 1 integron gene cassettes harboring resistance genes among MDR strains shows the potential of integrons to carry and spread resistance genes to other S. enterica isolates or to other bacteria. Therefore, a more prudent use of antibiotics in both humans and animals is required.

\section{Methods}

\section{Ethical approval}

This study was approved by Zagazig University, Egypt ethical board (Protocol No. 10122). Permission to collect stool samples was obtained from the administrators of Al-Ahrar General hospital.

\section{Specimen collection}

The present work was conducted during the period from March, 2014 to February, 2015. A total of one hundred fresh poultry carcasses comprising broiler chicken and ducks (50, each) were randomly purchased from poultry retail outlets at Zagazig City, Egypt. In addition, fifty stool samples were collected from the patients attending the outpatients' clinic of Al-Ahrar General Hospital. The inclusion criteria were restricted to the patients who suffered from diarrhoea, fever and gave informed written consent to participate in the study. Moreover, patients received antibiotic treatments were excluded. A swab was obtained from each freshly passed stool sample, labeled, ice packed and transported to the Bacteriology Laboratory, Faculty of Veterinary Medicine, Zagazig University, Egypt within $24 \mathrm{~h}$ for bacteriological analysis.

\section{Isolation and identification of Salmonella spp}

Salmonella isolation was carried out according to the standard methods recommended by ISO 6579 [33]. Twenty-five grams of poultry meat were excised from each sample and minced with $225 \mathrm{ml}$ of buffered peptone water (BPW) enrichment broth. Also, each stool swab was inserted in sterile tube containing $9 \mathrm{ml} \mathrm{BPW}$. All samples were incubated at $37^{\circ} \mathrm{C}$ for $24 \mathrm{~h}$. Aliquots $(0.1 \mathrm{ml})$ of the pre-enriched culture was inoculated into $10 \mathrm{ml}$ of Rappaport Vasiliadis (RV) enrichment broth and incubated at $42{ }^{\circ} \mathrm{C}$ for $24 \mathrm{~h}$. A loopful of the enriched culture was streaked on Xylose-Lysine-Deoxycholate (XLD) agar plates (Oxoid, Basingstoke, UK) and incubated at $37{ }^{\circ} \mathrm{C}$ for $24 \mathrm{~h}$. Suspected colonies with typical Salmonella morphology were confirmed biochemically by indole, citrate utilization, urease, triple sugar iron (TSI) and lysine iron agar (LIA) tests. All biochemically confirmed Salmonella isolates were serologically identified on the basis of somatic $(\mathrm{O})$ and flagellar $(\mathrm{H})$ antigens by slide agglutination using commercial antisera (SISIN,
Berlin) following Kauffman-White scheme [34] in collaboration with Serology Unit, Animal Health Research Institute, Dokki, Egypt.

\section{Antimicrobial susceptibility testing (antibiogram)}

Susceptibility of Salmonella isolates to various routine antimicrobial drugs was tested by the standard disc diffusion technique [35] using Mueller-Hinton agar and commercial antibiotic discs (Oxoid, UK). The antibiotics used were ampicillin $(10 \mu \mathrm{g})$, erythromycin $(15 \mu \mathrm{g})$, streptomycin $(10 \mu \mathrm{g})$, ciprofloxacin $(5 \mu \mathrm{g})$, tetracycline $(30 \mu \mathrm{g})$, ceftriaxone $(30 \mu \mathrm{g})$, ampicillin-sulbactam $(20 \mu \mathrm{g})$, trimethoprim-sulfamethoxazole $(25 \mu \mathrm{g})$, chloramphenicol $(30 \mu \mathrm{g})$, nalidixic acid $(30 \mu \mathrm{g})$, gentamicin $(10 \mu \mathrm{g})$, amoxicillin-clavulanic acid $(30 \mu \mathrm{g})$. The inhibition zones in $\mathrm{mm}$ were measured and scored as sensitive, intermediate and resistant categories in accordance with the critical breakpoints recommended by the Clinical and Laboratory Standards Institute [36].

\section{Molecular detection of Salmonella virulence genes using uniplex PCR}

A total of twelve Salmonella isolates were screened for the presence of virulence genes using PCR. These genes including; plasmid encoded fimbriae (pefA), hyper invasive locus (hilA), Salmonella outer protein ( $\operatorname{sop} \mathrm{B})$ and Salmonella enterotoxin gene $(s t n)$. Briefly, DNA was extracted from the overnight bacterial culture using ABIO pure Genomic DNA extraction kit with modifications from the manufacturer's recommendation. DNA amplification was carried out using specific primers supplied from Metabion, Germany (Table 4). Primers were utilized in a $25 \mu \mathrm{l}$ reaction containing $12.5 \mu \mathrm{l}$ of Emerald Amp Max PCR Master Mix (Takara, Japan), one $\mu \mathrm{l}$ of each primer ( $20 \mathrm{pmol}$ concentration), $4.5 \mu \mathrm{l}$ of nuclease free water, and $6 \mu \mathrm{l}$ of DNA template. The reaction was performed in a T3 Biometra thermal cycler. Positive and negative controls were included in each reaction. Aliquot of each amplicon along with a $100 \mathrm{bp}$ molecular weight DNA ladder (Fermentas, USA) were separated by electrophoresis on $1.5 \%$ agarose gel (Applichem, Germany, $\mathrm{GmbH}$ ) stained with $0.5 \mu \mathrm{g} / \mathrm{ml}$ ethidium bromide (Sigma, USA) in $1 \times$ TBE buffer on a mini slab horizontal electrophoresis unit (Bio-Rad, USA) at $100 \mathrm{~V}$ for $30 \mathrm{~min}$. The gel was photographed by a gel documentation system (Alpha Innotech, Biometra) and the data was analyzed through computer software.

\section{Molecular detection and sequencing of class 1 integrons}

All MDR Salmonella isolates $(\mathrm{n}=12)$ were tested for the presence of conserved regions (5'-CS and $\left.3^{\prime}-\mathrm{CS}\right)$ of class I integrons using specific primers with the following sequences: 5' CS-GGC ATC CAA GCA GCA AG and 
Table 4 Primers' sequences and amplification's conditions used for detection of Salmonella virulence genes

\begin{tabular}{|c|c|c|c|c|c|c|c|c|}
\hline \multirow{2}{*}{$\begin{array}{l}\text { Target } \\
\text { gene }\end{array}$} & \multirow[t]{2}{*}{ Primers' sequences $5^{\prime}-3^{\prime}$} & \multirow{2}{*}{$\begin{array}{l}\text { Amplified } \\
\text { segment } \\
\text { (bp) }\end{array}$} & \multirow{2}{*}{$\begin{array}{l}\text { Primary } \\
\text { denaturation }\end{array}$} & \multicolumn{3}{|c|}{ Amplification ( 35 cycles) } & \multirow{2}{*}{$\begin{array}{l}\text { Final } \\
\text { extension }\end{array}$} & \multirow[t]{2}{*}{ References } \\
\hline & & & & $\begin{array}{l}\text { Secondary } \\
\text { denaturation }\end{array}$ & Annealing & Extension & & \\
\hline \multirow[t]{2}{*}{ pefA } & TGTTTCCGGGCTTGTGCT & 700 & $94^{\circ} \mathrm{C} 10 \mathrm{~min}$ & $94^{\circ} \mathrm{C} 45 \mathrm{~s}$ & $55^{\circ} \mathrm{C} 45 \mathrm{~s}$ & $72{ }^{\circ} \mathrm{C} 45 \mathrm{~s}$ & $72^{\circ} \mathrm{C} 10 \mathrm{~min}$ & {$[4]$} \\
\hline & CAGGGCATTTGCTGATTCTTCC & & & & & & & \\
\hline \multirow[t]{2}{*}{ hilA } & CGGAAGCTTATTTGCGCCATGCT GAGGTAG & 854 & $94^{\circ} \mathrm{C} 10 \mathrm{~min}$ & $94^{\circ} \mathrm{C} 45 \mathrm{~s}$ & $60^{\circ} \mathrm{C} 45 \mathrm{~s}$ & $72^{\circ} \mathrm{C} 45 \mathrm{~s}$ & $72^{\circ} \mathrm{C} 10 \mathrm{~min}$ & {$[37]$} \\
\hline & GCATGGATCCCCGCCGGCGAGATTGTG & & & & & & & \\
\hline \multirow[t]{2}{*}{ sopB } & TCAGAAGRCGTCTAACCACTC & 517 & $94^{\circ} \mathrm{C} 5 \min$ & $94^{\circ} \mathrm{C} 30 \mathrm{~s}$ & $58^{\circ} \mathrm{C} 30 \mathrm{~s}$ & $72{ }^{\circ} \mathrm{C} 30 \mathrm{~s}$ & $72^{\circ} \mathrm{C} 7 \mathrm{~min}$ & [38] \\
\hline & TACCGTCCTCATGCACACTC & & & & & & & \\
\hline \multirow[t]{2}{*}{$\operatorname{stn}$} & TTGTGTCGCTATCACTGGCAACC & 617 & $94^{\circ} \mathrm{C} 10 \mathrm{~min}$ & $94^{\circ} \mathrm{C} 45 \mathrm{~s}$ & $59^{\circ} \mathrm{C} 45 \mathrm{~s}$ & $72{ }^{\circ} \mathrm{C} 45 \mathrm{~s}$ & $72^{\circ} \mathrm{C} 10 \mathrm{~min}$ & {$[4]$} \\
\hline & ATTCGTAACCCGCTCTCGTCC & & & & & & & \\
\hline
\end{tabular}

3'CS- AAG CAG ACT TGA CCT GA [30]. Chromosomal DNA extraction, amplification and gel analysis were performed as mentioned before except to amplify the DNA in the thermal cycler we used a three-step profile (cycling conditions): $1 \mathrm{~min}$ of denaturation at $94{ }^{\circ} \mathrm{C}, 1 \mathrm{~min}$ of annealing at $55^{\circ} \mathrm{C}$, and $5 \mathrm{~min}$ of extension at $72{ }^{\circ} \mathrm{C}$ for a total of 35 cycles. Five seconds were added to the extension time at each cycle. Amplified products with variable sizes were purified using QIA quick PCR Product extraction kit (Qiagen, Valencia). Each purified amplicon was sequenced in both forward and reverse directions using the amplification primers. DNA sequences were obtained by Applied Biosystems 3130 genetic analyzer (HITACHI, Japan).Nucleotide sequence analysis was compared with published GenBank DNA sequences using NCBI BLAST program (http://www.ncbi.nlm.nih.gov/BLAST/) and alignment was performed usingMEGA6 program.

\section{Nucleotide sequence accession numbers}

Nucleotide sequences from this study were deposited into the GenBank under accession numbers [KT427378, KT449569, KT449570, KT449571, KT581253, KT581254, KT581255, KT581256, KT581257 and KT598359].

\section{Authors' contributions}

RMG, YHT and MHE participated in the design of the study, collected and analyzed the samples. YHT participated in the sequence alignment. RMG and YHT drafted the manuscript. All authors read and approved the final manuscript.

\footnotetext{
Author details

${ }^{1}$ Depatment of Zoonoses, Faculty of Veterinary Medicine, Zagazig University, 44511 Zagazig, Egypt. ${ }^{2}$ Department of Bacteriology, Mycology and Immunology, Faculty of Veterinary Medicine, Zagazig University, 44511 Zagazig, Egypt. ${ }^{3}$ Department of Veterinary Public Health, Faculty of Veterinary Medicine, Zagazig University, 44511 Zagazig, Egypt.
}

\section{Aknowledgements}

We are grateful to thank all administrators and clinicians in Al-Ahrar General Hospital, Zagazig, Egypt for their assistance in collecting stool samples.

\section{Competing interests}

The authors declare that they have no competing interests.
Received: 17 September 2015 Accepted: 10 December 2015 Published online: 23 December 2015

\section{References}

1. Majowicz SE, Musto J, Scallan E, Angulo FJ, Kirk M, O'Brien SJ, et al. The global burden of non-typhoidal Salmonella gastroenteritis. Clin Infect Dis. 2010;50:882-9.

2. EFSA (European Food Safety Authority). The community summary report on trends and sources of zoonoses and zoonotic agents in the European Union in 2007. EFSA J. 2009;223:312. doi:10.2903/j.efsa.2009.223r.

3. Lostroh CP, Bajaj $\mathrm{V}$, Lee CA. The cis requirements for transcriptional activation by HilA, a virulence determinant encoded on SPI-1. Mol Microbiol. 2000;37:300-15.

4. Murugkar HV, Rahman H, Dutta PK. Distribution of virulence genes in Salmonella serovars isolated from man and animals. Indian J Med Res. 2003;117:66-70.

5. Van Asten AJ, van Dijk JE. Distribution of classic virulence factors among Salmonella spp. FEMS Immunol Med Microbiol. 2005;44:251-9.

6. Threlfall EJ. Antimicrobial drug resistance in Salmonella: problems and perspectives in food- and water-borne infections. FEMS Microbiol Rev. 2002;26:141-8

7. Chu C, Chiu CH. Evolution of the virulence plasmids of non-typhoidal Salmonella and its association with antimicrobial resistance. Microbes Infect. 2006;8(7):1931-6.

8. Rowe-Magnus DA, Mazel D. The role of integrons in antibiotic resistance gene capture. Int J Med Microbiol. 2002;292(2):115-25.

9. Maharjan M, Joshi V, Joshi DD, Manandhar P. Prevalence of Salmonella species in various raw meat samples of a local market in Kathmandu. Trends in the study of disease agents. Ann N Y Acad Sci. 2006;1081:249-56.

10. Arsenault J, Letellier A, Quessy S, Boulianne M. Prevalence and risk factors for Salmonella and Campylobacter spp. carcass contamination in broiler chickens slaughtered in Quebec, Canada. J Food Prot. 2007;70(8):1820-8.

11. Kaushik P, Anjay Kumari S, Bharti SK, Dayal S. Isolation and prevalence of Salmonella from chicken meat and cattle milk collected from local markets of Patna, India. Vet World. 2014;7(2):62-5.

12. Murugkar HV, Rahman H, Kumar A, Bhattacharyya D. Isolation, phage typing \& antibiogram of Salmonella from man and animals in northeastern India. Indian J Med Res. 2005;122:237-42.

13. Vo ATT, Duijkeren EV, Fluit AC, Wannet WJB, Verbruggen AJ, Maas HME, et al. Antibiotic resistance, integrons and Salmonella genomic island 1 among non-typhoidal Salmonella serovars in the Netherlands. Int J Antimicrob Agents. 2006;28(3):172-9.

14. Dione MM, Ikumapayi U, Saha D, Mohammed NI, Adegbola RA, Geerts $\mathrm{S}$, et al. Antimicrobial resistance and virulence genes of non-typhoidal Salmonella isolates in the Gambia and Senegal. J Infect Dev Ctries. 2011;5(11):765-75. 
15. Soomro AH, Khaskheli M, Bhutto MB, Shah G, Memon A, Dewani P. Prevalence and antimicrobial resistance of Salmonella serovars isolated from poultry meat in Hyderabad, Pakistan. Turk J Vet Anim Sci. 2010;34(5):455-60.

16. Onyango D, Machoni F, Kakai R, Waindi EN. Multidrug resistance of Salmonella enterica serovars Typhi and Typhimurium isolated from clinical samples at two rural hospitals in Western Kenya. J Infect Dev Ctries. 2008;2(2):106-11.

17. Akbarmehr J. Isolation of Salmonella spp. from poultry (ostrich, pigeon, and chicken) and detection of their hilA gene by PCR method. Afr J Microbiol Res. 2010;4(24):2678-81.

18. Rahman H. Prevalence \& phenotypic expression of sopB gene among clinical isolates of Salmonella enterica. Indian J Med Res. 2006;123:83-8.

19. Lindstedt BA, Heir E, Nygard I, Kapperud G. Characterization of class I integrons in clinical strains of Salmonella enterica subsp. enterica serovars Typhimurium and Enteritidis from Norwegian hospitals. J Med Microbiol. 2003:52:141-9.

20. Antunes P, Machado J, Peixe L. Characterization of antimicrobial resistance and class 1 and 2 integrons in Salmonella enterica isolates from different sources in Portugal. J Antimicrob Chemother. 2006;58:297-304.

21. Cabrera R, Ruiz J, Sanchez-Cespedes J, Gómez-Lus R, Jiménez de Anta MT, Gascón J, et al. Characterization of the enzyme aac (3)-Id in a clinical isolate of Salmonella enterica serovar Haifa causing traveler's diarrhea. Enferm Infecc Microbiol Clin. 2009;27(8):453-6.

22. Doublet B, Weill FX, Fabre L, Chaslus-Dancla E, Cloeckaert A. Variant Salmonella genomic island 1 antibiotic resistance gene cluster containing a novel 3-N-aminoglycoside acetyltransferase gene cassette, aac (3)-Id in Salmonella enterica serovar Newport. Antimicrob Agents Chemother. 2004;48(10):3806-12.

23. Levings RS, Partridge SR, Lightfoot D, Hall RM, Djordjevic SP. New integron-associated gene cassette encoding a 3-N- aminoglycoside acetyltransferase. Antimicrob Agents Chemother. 2005;49(3):1238-41.

24. Casin I, Hanau-Bercot B, Podglajen I, Vahaboglu H, Collatz E. Salmonella enterica serovar Typhimurium blaPER-1-carrying plasmid pSTI1 encodes an extended-spectrum aminoglycoside 6-N-acetyltransferase of type lb. Antimicrob Agents Chemother. 2003;47(2):697-703.

25. Sabtcheva S, Galimand M, Gerbaud G, Courvalin P, Lambert T. Aminoglycoside resistance gene ant(4)-IIb of Pseudomonas aeruginosa BM4492, a clinical isolate from Bulgaria. Antimicrob Agents Chemother. 2003;47(5):1584-8.
26. Michael GB, Cardoso M, Schwarz S. Class 1 integron-associated gene cassettes in Salmonella enterica subsp. enterica serovar Agona isolated from pig carcasses in Brazil. J Antimicrob Chemother. 2005;55:776-9.

27. Vo ATT, van Duijkeren E, Gaastra W, Fluit AC. Antimicrobial Resistance, class 1 integrons, and genomic island 1 in Salmonella isolates from Vietnam. PLoS One. 2010;5:e9440.

28. Chiu CH, Tang P, Chu C, Hu S, Bao Q, Yu J, et al. The genome sequence of Salmonella enterica serovar Choleraesuis, a highly invasive and resistant zoonotic pathogen. Nucleic Acids Res. 2005;33:1690-8.

29. Krauland MG, Marsh JW, Paterson DL, Harrison LH. Integron-mediated multidrug resistance in a global collection of non-typhoidal Salmonella. Emerg Infect Dis. 2009;15(3):388-96.

30. Lévesque C, Piché L, Larose C, Roy PH. PCR mapping of integrons reveals several novel combinations of resistance genes. Antimicrob Agents Chemother. 1995;39(1):185.

31. Wiesner M, Zaidi MB, Calva E, Fernández-Mora M, Calva JJ, Silva C. Association of virulence plasmid and antibiotic resistance determinants with chromosomal multilocus genotypes in Mexican Salmonella enterica serovar Typhimurium strains. BMC Microbiol. 2009;9:131.

32. Douadi B, Thong KL, Watanabe H, Puthucheary SD. Characterization of drug resistant Salmonella enterica serotype Typhimurium by antibiograms, plasmids, integrons, resistance genes and PFGE. J Microbiol Biotechnol. 2010;20(6):1042-52.

33. ISO (6579). Microbiology of food and animal feeding stuffs-horizontal method for the detection of Salmonella spp. Geneva: ISO; 2002.

34. Popoff MY, Bockemuhl J, Gheesling LL. Supplement 2002 (no. 46) to the Kauffmann-White scheme. Res Microbiol. 2004;155:568-70.

35. Bauer AW, Kirby WMM, Sherris JC. Antibiotic susceptibility testing by a standardized single disc. Am J Clin Pathol. 1966;45:493-6.

36. Clinical and Laboratory Standards Institute (CLSI). Performance standards for antimicrobial susceptibility testing; Eighteenth informational supplement. Wayne: CLSI document M100-S20; 2010.

37. Cardona- Castro N, Restrepo-Pineda E, Correa-Ochoa M. Detection of hilA gene sequences in serovars of Salmonella enterica subspecies enterica. Mem Inst Oswaldo Cruz. 2002;97:1153-6.

38. Huehn S, La Ragione RM, Anjum M, Saunders M, Woodward MJ, Bunge $C$, et al. Virulotyping and antimicrobial resistance typing of Salmonella enterica serovars relevant to human health in Europe. Food borne Pathog Dis. 2010;7:523-35.

\section{Submit your next manuscript to BioMed Central and we will help you at every step:}

- We accept pre-submission inquiries

- Our selector tool helps you to find the most relevant journal

- We provide round the clock customer support

- Convenient online submission

- Thorough peer review

- Inclusion in PubMed and all major indexing services

- Maximum visibility for your research

Submit your manuscript at www.biomedcentral.com/submit

\section{() Biomed Central}

